\title{
Bionomics of the Pear Bud Mite Eriophyes pyri (Pagenstecher) (Acari: Eriophyidae) in Egypt
}

\author{
B. A. Abou-Awad"; S. I. Afia* and M. M. Al-Azzazy ${ }^{* *}$ \\ *Plant Protection Dept., National Research Centre, Dokki, Cairo, Egypt \\ *** Dept. of Agric. Zoology and Nematology, Faculty of Agric., Al-Azhar Univ., Cairo, Egypt
}

\begin{abstract}
Population of the pear bud mite Eriophyes pyri (Pagenstecher) was observed for one year in an abandoned apple orchard in Egypt. Its population dynamics were affected by climatic conditions and vertical distribution. Mite density within the buds increased in spring, summer and winter recording three peaks in early March, early July and midDecember. About 11generations were recorded on Anna apple cultivar. Buds at middle level of trees were found preferable to the mite infestation than those at top and bottom. The mite successfully developed from egg to adult when reared on terminal buds of soft divided apple branches dipped in test tubes at $26 \pm 1{ }^{\circ} \mathrm{C}$ and $70 \pm 5 \%$ R.H. Life table parameters showed that the mean generation time was (17.51 days) and population increase Ro 10.93 times. The finite rate of increase $\left(\mathrm{e}^{\mathrm{rm}}\right)$ was 1.14 times / + /day.
\end{abstract}

Key Words: Ecology; Biology; Eriophyes pyri; Eriophyidae; Acari; Life table parameters; Apple.

\section{INTRODUCTION}

Some apple orchards in Egypt have recently suffered from infestation with the pear bud mite or pear blister mite Eriophyes pyri (Pagenstecher). Its injury has greatly increased during the last three years. The injury caused great damage to apple and pear. In Egypt, it is noted mainly on apple buds and rarely on pear trees (Abou-Awad, 1976). There are two races of this harmful mite, one that attacks buds while the other produces galls or blisters on the leaves. Adults spend winter in colonies under the scales of the fruit or vegetative buds. The most familiar symptoms caused by the pear bud mite are distorted and scabby appearance of the fruits that develop from infested fruit buds, the entire apple tree may be weakened and the foliage is spare and consists of stunted and misshapen leaves. However, this study presents information on the seasonal trend, behaviour and densities of the eriophyid bud mite on apple trees. Life history and life table parameters under laboratory conditions were also studied.

\section{MATERIALS AND METHODS}

\section{Ecological studies:}

Ecological studies on the pear bud mite E. pyri were carried out in abandoned apple orchards (Malus domestica Borb.), seven years old, near Giza, for a whole year (Feb. 2009 to Jan. 2010). In order to provide comparative measures of eriophyids under different conditions, ten apple trees of similar size, vigor and shape from Anna cultivar were selected. Samples of lateral and terminal buds were taken weekly. Buds were cut to their leaf scales and examined to assess numbers of $E$. pyri. stages.
To determine the number of annual generations of E. pyri under the local environmental conditions, the percentage of immature stages was estimated weekly. The time at which the highest percentage of the immatures to all moving stages occurred represented the beginning of a new generation.

To study the comparative abundance of terminal and lateral buds and vertical distribution of E. pyri, ten lateral and ten terminal buds were collected randomly from top, bottom and middle of Anna apple cultivars. Observations were made for one year from February 2009 to January 2010. Samplings were performed on the $15^{\text {th }}$ of every month. In the present investigation, buds of apple trees from the upper $50-70 \mathrm{~cm}$ of the tree branches, represented the "top-level buds" while those on the branches of the trees up to $100-120 \mathrm{~cm}$ above ground level, represented the bottom-level buds. The buds between the top and the bottom level were regarded as "middle-level buds".

\section{Biological studies:}

The method described by Abou-Awad et al. (2005) for rearing the eriophyid mites were followed. Soft terminal apple branches with terminal buds of $15-20 \mathrm{~cm}$ were washed and all attached leaves were removed for each branch to rear the pear bud mite, E. pyri between owter first and second bracts of the buds. Cuttings were dipped for two seconds, into indol acetic acid to encourage developing roots, before inserting into tubes contained prepared medium. Thirty adult mites were placed singly between owter bracts of the buds. Each female was allowed to deposit 1-2 eggs, then removed. Table of tubes was placed in the incubator and the development of mite was observed twice 
daily. Insemination took place soon after male and female emergence, each newly virgin female was transferred for $24 \mathrm{~h}$, to owter bracts of the bud previously inhabited by an adult emerged male, to allow insemination by spermatophores, then females and males were transferred to their previous substrates. According to ecological study, experiments were conducted under laboratory conditions of $26 \pm 1^{\circ} \mathrm{C}, 70 \pm 5 \%$ R.H. and photoperiod $12 / 12 \mathrm{~h}$ light/dark. Life table parameters were calculated according to a Basic computer program (Hulting et al., 1999).

\section{RESULTS AND DISCUSSION}

The pear bud mite E. pyri does not hibernate throughout the winter and remains feeds in the apple buds during the whole year, preferably under the second and third layers of the bud scales or in depressions or groves more or less concealed by the pubescence of bud scales. Winter, fall, spring and summer activities vary according to climatic conditions.

During early spring, when the fruit buds open, the mites move to the young sap filled growth points and move on the apple trees from that time that the buds open until the scales of new buds are sufficiently loose to permit invasion to take place. During the migratory period, mites are found clustered about the leaf buds. At this time they are quite exposed, and therefore this period is apparently the most practical time to destroy them. After they are hidden under the fruit bud scales, it is almost impossible to destroy them with nonsystemic acaricides as they are protected. Egg deposition soon starts within the bud and the mites develop, continue to multiply throughout the winter. Mites feed on and destroy the white tissue at the base of the bud scales and later on the floral parts enclosed in the bud. At blooming, many of the fruit buds fail to open at all, while others open with only one or two blossoms and the bloom is weak, often fails to set and frequently drops.

The population dynamics of the pear bud mite, $E$. pyri for a 1-year study on the apple trees (Anna cultivar) and weather records are presented in Fig. 1. Climatic conditions and the occurrence under scales of fruit and vegetative buds during a whole year may have a role to play. The mite population started to increase in February then reached a first peak in early March. The population sharply declined in April and May, then increased again reaching a second peak in early July and fluctuated in August, September, October and November reaching a third peak in mid-December (2009) and tailed off at the end of January (2010). The highest population occurred in March (spring), July (summer) and December (winter) of the one study year, averaging 23.00,27.50 and 18.70 mite individuals per bud in 2009 at average temperature $20,30 \& 17^{\circ} \mathrm{C}$ and 39 , $49 \& 59 \%$ relative humidity (R.H.), respectively. Significant positive correlation was noted between mite population and both temperature $(0.503)$ and relative humidity $(0.250)$. The data obtained are in agreement with those reported by Al-Azzazy (2010).

About 11 generations of E. pyri were recorded on fruit and vegetative apple buds per year (Feb 2009Jan 2010). The longest generation occurred in fall season and lasted for about seven weeks, while the shortest one occurred in summer and lasted for about three weeks (Fig.2). This confirms that the changeable environmental factors had generally great effect on the pear bud mite E. pyri. The severe damage occurred in fall and mid-winter, when the vegetative and fruit buds may be attacked and completely damaged.

The numerical changes in vertical distribution of the bud mite on Anna apple trees for one year, with temperatures and relative humidities are given in Fig. 3. The mite population at top and middle reached a peak mostly during July, then declined gradually till November. At the bottom level, buds had nearly similar mite population in comparison with the top level. The data suggest that the middle buds were preferable to the mite feeding and were useful for sampling of the eriophyid mite population to evolve suitable strategies in integrated pest management (IPM) program.

According to the previous ecological study, $E$. pyri was able to develop successfully from egg to adult, through the entire life history at the optimal conditions for its development $\left(26 \pm \mathrm{I}^{\mathrm{O}} \mathrm{C}\right.$ and $70 \pm 5 \%$ R.H.). The mean developmental periods, oviposition and survival rate are shown in table 1 . Eggs are elongate, oval, with blunt rounded ends, averaging $45 \mu \mathrm{m}$ long by $33 \mu \mathrm{m}$ wide and pearly white when first laid, later becoming opaque as a result of development of the embryo. E. pyri commences life as an egg, passes through two immature stages, (a larva and a nymph), and finally emerges as an adult. A quiescent stage occurs between the larva and nymph (the nymphochrysalis) and again between the nymph and adult (the imagochrysalis). During quiescent stage larvae and nymphs take a pearly cluster. Just prior to the moulting, the new integument can be seen under the old one. Larva possesses fewer abdominal rings and 


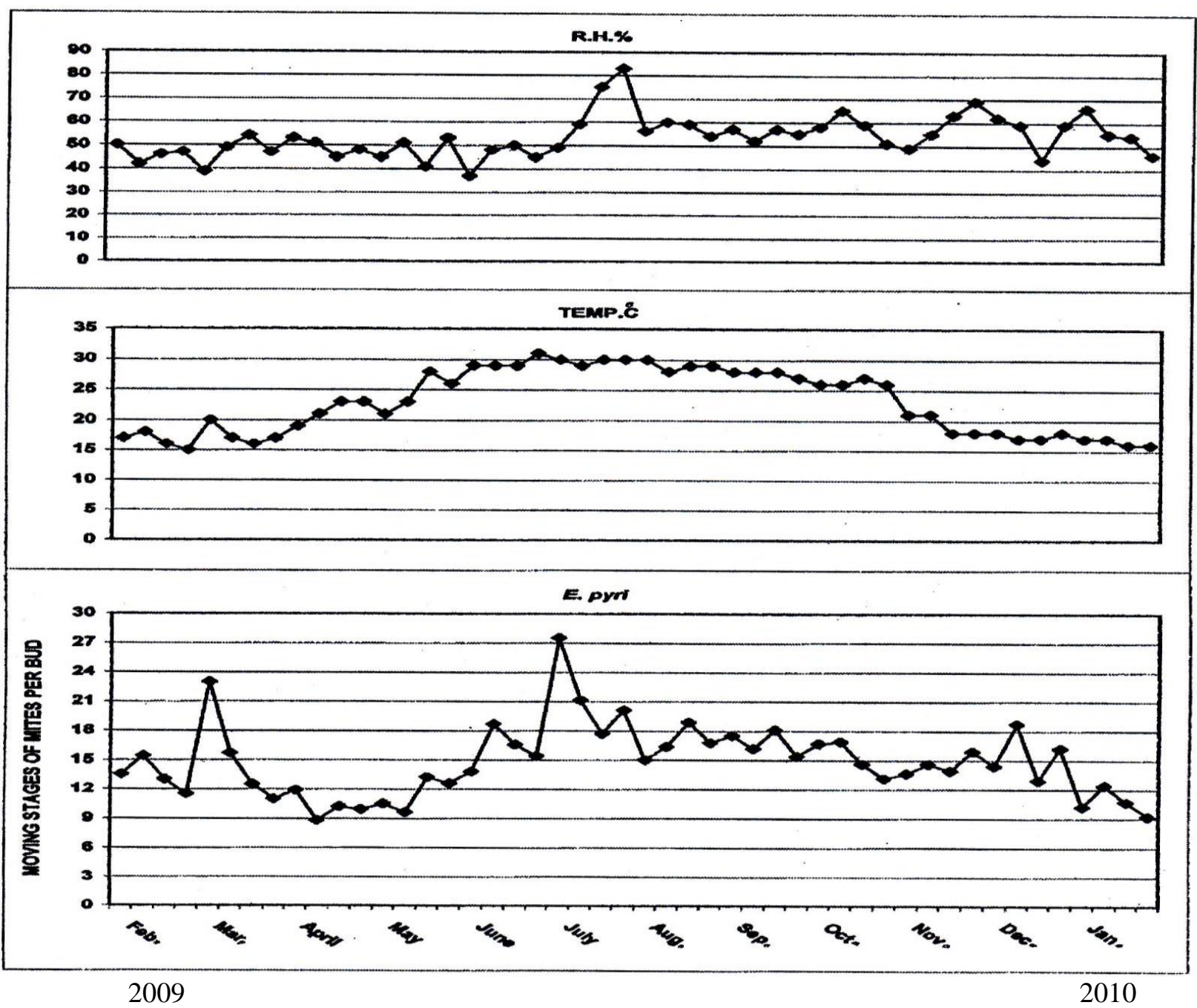

Fig. (1): Population density of the pear bud mite, E. pyri on Anna apple buds in abandoned orchard from February 2009 to January 2010 and weather records.

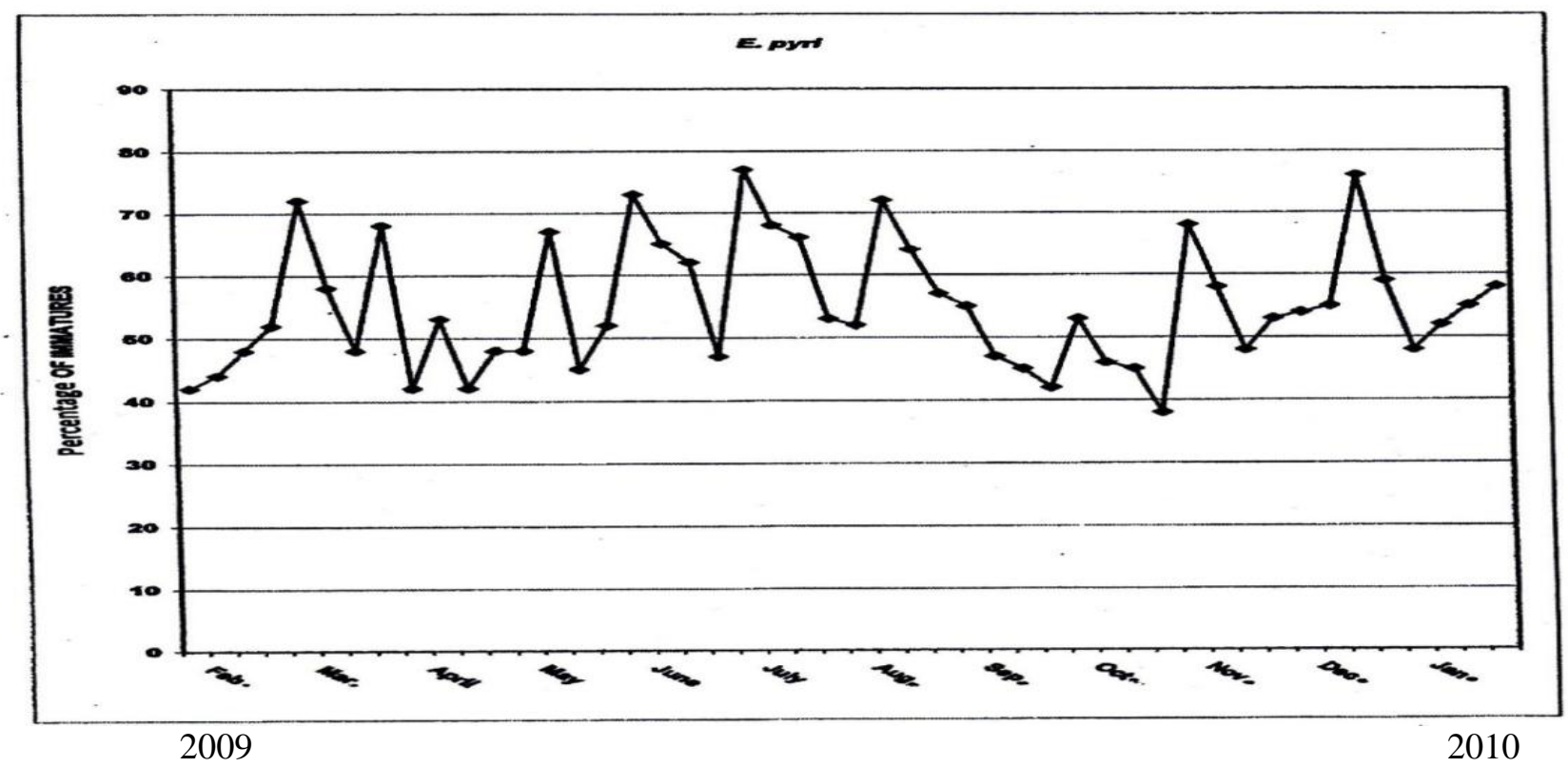

Fig. (2): Perentage of immature stages in the total population of the pear bud mite, E. pyri on Anna apple buds in abandoned orchard from Feruary 2009 to January 2010. 

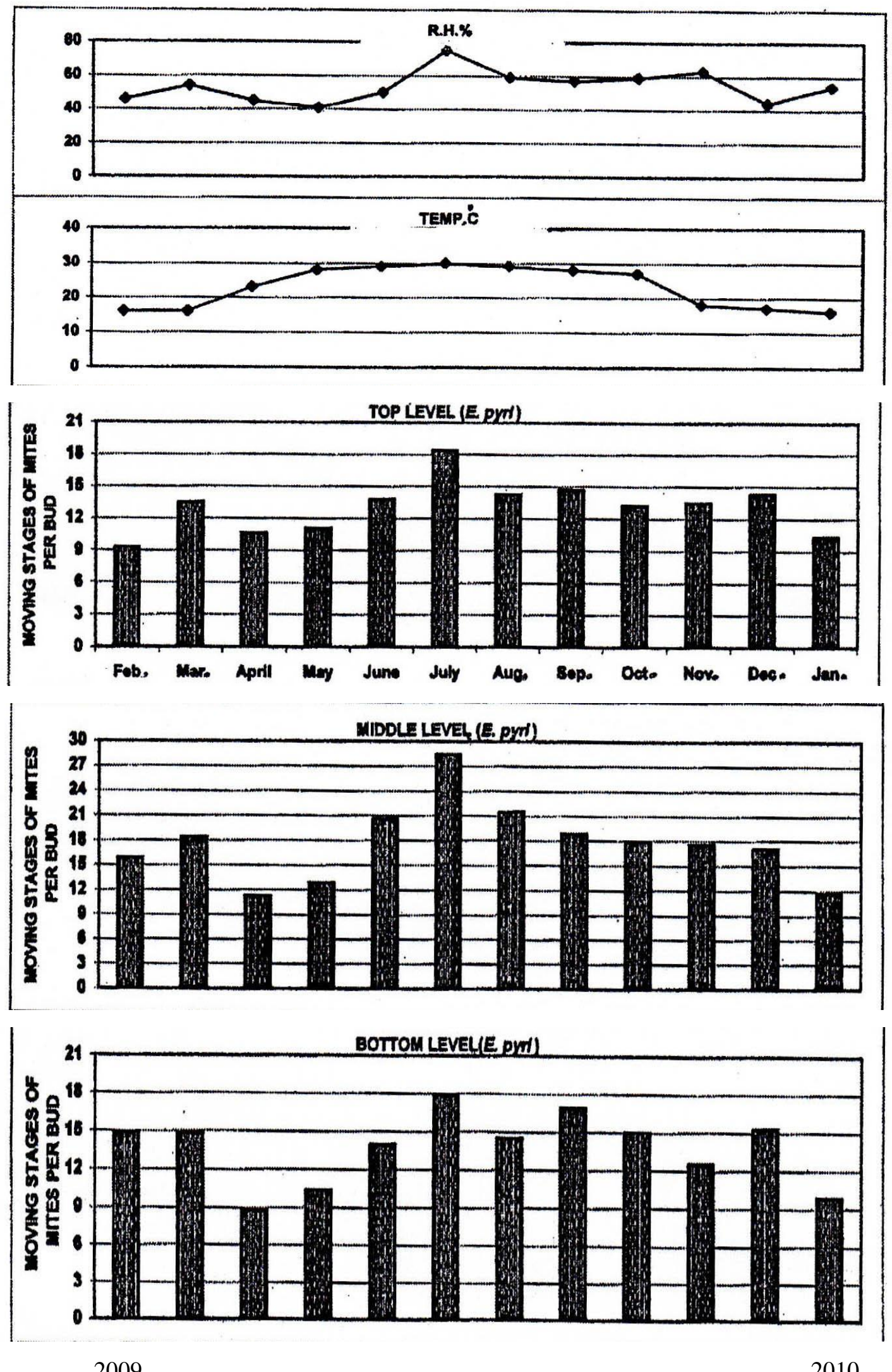

Fig. (3): Population trends of the pear bud mite, E. pyri on Anna apple buds in abandoned orchard from February 2009 to January 2010 and weather records. 
Table1. Average duration in days of various stages and oviposition rate of Eriophyes pyri reared on apple buds at $26 \pm 1^{\circ} \mathrm{C}$ and $70 \pm 5 \%$ R.H.

\begin{tabular}{|c|c|c|}
\hline $\begin{array}{l}\text { Mite stage } \\
\text { and fecundity }\end{array}$ & Sex & $\begin{array}{c}\text { E. pyri } \\
\text { Mean } \pm \text { SD }\end{array}$ \\
\hline \multirow{2}{*}{ Egg } & Female & $3.71 \pm 0.13$ \\
\hline & Male & $3.50 \pm 0.13$ \\
\hline \multirow[t]{2}{*}{ First stage (Larva) } & Female & $2.01 \pm 0.15$ \\
\hline & Male & $1.97 \pm 0.15$ \\
\hline \multirow[t]{2}{*}{ Nymphochrysalis } & Female & $0.24 \pm 0.08$ \\
\hline & Male & $0.22 \pm 0.09$ \\
\hline \multirow[t]{2}{*}{ Second stage (Nymph) } & Female & $1.91 \pm 0.16$ \\
\hline & Male & $1.77 \pm 0.19$ \\
\hline \multirow[t]{2}{*}{ Imagochrysalis } & Female & $0.21 \pm 0.08$ \\
\hline & Male & $0.20 \pm 0.08$ \\
\hline \multirow[t]{2}{*}{ Total } & Female & $8.08 \pm 0.17$ \\
\hline & Male & $7.66 \pm 0.19$ \\
\hline Pre-oviposition & Female & $2.09 \pm 0.21$ \\
\hline Generation & Female & $10.17 \pm 0.14$ \\
\hline Oviposition & Female & $16.03 \pm 0.63$ \\
\hline Total fecundity (eggs) & Female & $17.00 \pm 0.71$ \\
\hline Post-oviposition & Female & $3.19 \pm 0.09$ \\
\hline \multirow[t]{2}{*}{ Longevity } & Female & $21.31 \pm 1.03$ \\
\hline & Male & $19.93 \pm 1.05$ \\
\hline \multirow[t]{2}{*}{ Life span } & Female & $29.39 \pm 1.11$ \\
\hline & Male & $27.59 \pm 1.31$ \\
\hline \multirow[t]{2}{*}{ Survivial \% } & Female & 100 \\
\hline & Male & 100 \\
\hline \multirow[t]{2}{*}{ Number of observations } & Female & 20 \\
\hline & Male & 10 \\
\hline
\end{tabular}

Table 2. Life table parameters of the pear bud mite E. pyri reared on apple buds at $26 \pm{ }^{\circ} \mathrm{C}$ and $70 \pm 5 \%$ R.H.

\begin{tabular}{lc}
\hline \multicolumn{1}{c}{ Parameters } & E. pyri \\
\hline Net reproductive rare (Ro) & 10.93 \\
Mean generation time (T) & 17.51 \\
Intrinsic rate of increase $(\mathrm{rm})$ & 0.127 \\
Finite rate of increase $\left(\mathrm{e}^{\mathrm{rm}}\right)$ & 1.135 \\
$50 \%$ mortality in days & 27 \\
Sex ratio (female/total) & $20 / 30$ \\
Sex ratio (female/Male) & $2.00: 1$ \\
\hline
\end{tabular}

the prosoma is longer in relation to the rest of the body; while the nymph possesses more striations than those of larva but fewer than adult. Moulting behaviour of $E$. pyri was similar to the olive bud mite, Aceria oleae alepa (Abou-Awad et al., 2005) and the peach silver mite Aculus fockeui (AbouAwad et al., 2010).

The entire life cycle was completed within a period of 8.08 and 7.66 days for female and male, respectively; male developed faster. As in other eriophyoid mites, the male of this species produced spermatophores which attached to the host plant (within buds) by a curved stalks and fertilization occurred when the female drew the spermatophore into the genital orifice. Fertilization occurred at the feeding sites. Oldfield and Newell (1973) demonstrated that a few days after fertilization, the progeny was prodominantly female, with a sex ratio of $2: 1$; while unfertilized females produced only males. This is in agreement with the present results (Table 2). Similar fmdings were also reported on the olive bud mite A. oleae (Abou-Awad et al., 2005) and the mango bud mite A. mangiferae Sayed (Abou-Awad et al., 2011). A generation averaged 10.17 days; about $36 \%$ of which during the egg stage. Females deposited an average of 17 eggs during an oviposition period that averaged 16.03 days then survived for 3.19 days. The life history took an average of 29.39 and 27.59 days for female and male, respectively (Table 1 ).

Parameters of population growth of E. pyri are shown in Table 2. The intrinsic rate of increase (rm) value was 0.127 individual / 9 /day. During the mean generation time ( $\mathrm{T}=17.51$ days), a population would increase 10.93 times $(\mathrm{Ro}=10.93)$. It was also found that the finite rate of increase $\left(\mathrm{e}^{\mathrm{rm}}\right)$ was I.I 4 time /O/day. These statistics form one of the important components in an appraisal of the injury of E. pyri within closed apple buds.

\section{REFERENCES}

Abou-Awad, B. A. 1976. Incidence of eriophyoid mites in Egypt.Ph.D. Thesis. Cairo University, $196 \mathrm{pp}$.

Abou-Awad, B. A.; Al-Azzazy, M. M. and EI-Sawi S. A. 2010. The life-history of the peach silver mite, Aculus fockeui (Acari: Eriophyidae) in Egypt. Arch. Phytopath. and Plant Protec., 43: 384-389.

Abou-Awad, B. A; Metwally A. M. and Al-Azzazy, M. M. 2005. Environmental management and biological aspects of two eriophyid olive mites in Egypt: Aceria oleae and Tegolophus hassani. 
Z. Pflanzenkrankh. PfJanzensch., 112: 287-303. Abou-Awad, B. A.; Metwally, A. M. and AIAzzazy, M. M. 2011. Enviromental management and biological aspects of two eriophyid mango mites in Egypt: Aceria mangiferae and Metaculus mangiferae. Acarologia, 51: (In press).

Al-Azzazy, M. M. 2010. Biological aspects of pear bud mite Eriophyes pyri (Pagenstecher) (Acari: Eriophyidae) under different temperatures in Egypt. J. Plant Protec. \& Pathology, Mansoura
University, 1: 673-679.

Hulting , F. L. and Obrycki, J. J. 1999. A computer program for calculation and statistical comparison of intrinsic rate of increase and associated life table parameters. Florida Entomol., 73: 601-612.

Old field, O. N. and Newell, I. M. 1973. The role of the spermatophore in the reproductive biology of protogynes of Aculus cornutus (Acarina: Eriophyidae). Ann. Ent. Soc. Ann., 66: 160-163. 